\title{
FERMENTASI SUBSTRAT PADAT PADA ONGGOK DENGAN Aspergillus oryzae: EVALUASI KANDUNGAN PROTEIN DAN ASAM AMINO, KECERNAAN DAN KETERSEDIAAN ENERGI PADA AYAM BROILER
}

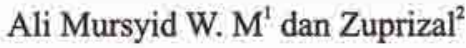

\begin{abstract}
INTISARI
Penelitian bertujuan untuk mempelajari kandungan protein, asam amino, kecernaan, dan ketersediaan energi pada onggok-fermentasi. Onggok difermentasi dengan Aspergillus oryzae secara aerobik menggunakan metode fermentasi substrat padat selama 72 (OF-72) dan 144 jam (OF-144), dan dilanjutkan inkubasi anaerobik selama 48 jam. Sampel OF-0, OF-72, dan OF-144 dianalisis kandungan protein kasar, protein terlarut, asam amino, dan energi bruto. Duabelas ayam broiler umur 12 minggu dipuasakan selama 24 jam, kemudian 9 diantaranya diberi pakan-uji berupa onggok-non fermentasi (OF-0), OF-72, dan OF-144 (masing-masing untuk 3 ayam), menggunakan teknik pelolohan basah. Pasca pemberian pakan-uji, semua ayam dipuasakan kembali selama periode $2 \times 24$ jam dan ekskreta dikoleksi. Sampel ekskreta diukur kandungan protein terlarut dan energi bruto. Variabel kecernaan yang diukur meliputi true digestibility of dry matter(TDDM), true digestibility of soluble protein (TDSP) dan apparent metabolizable energy (AME). Data dianalisis menggunakan ANOVA pola searah yang dilanjutkan Duncan's Multiple Range Test. Hasil penelitian menunjukkan bahwa dari OF-0 menjadi OF-72, kandungan protein kasar, protein terlarut, dan jumlah 14 asam amino meningkat berturut-turut sebesar 191, I12, dan 246\%. Dari OF-72 menjadi OF-144kandungan nutrien relatif tidak berubah, kecuali protein terlarut dan beberapa asam amino yang masih meningkat tajam. Nilai TDDM dan AME berubah tidak nyata dari OF-0 menjadi OF-72, kemudian menurun nyata $(\mathrm{P}<0,05)$ pada OF-144. Nilai TDSP meningkat nyata $(\mathrm{P}<0,05)$ dari $\mathrm{OF}-0$ menjadi $\mathrm{OF}-72$, kemudian menurun tidak nyata pada OF-144.
\end{abstract}

(Kata kunci : Onggok, Fermentasi, Aspergillus oryzae, Kecernaan, Ketersediaan energi, Broiler).

Buletin Peternakan $29(2): 71-78,2005$

${ }^{1} J u r u s a n$ Peternakan, Fakultas Pertanian, Universitas Veteran Bangun Nusantara, Sukoharjo.

${ }^{2}$ Fakultas Peternakan, Universitas Gadjah Mada, Yogyakarta. 


\title{
SOLID STATE - FERMENTATION ON CASSAVA POMACE WITH Aspergillus oryzae: THE EVALUATION OF PROTEINS AND AMINO ACIDS CONTENT, DIGESTIBILITY, AND BIOAVAILABILITY ENERGY FOR BROILER ROASTERS
}

\begin{abstract}
The objective of the research was to know the content of proteins, amino acids, digestibility and bioavailability energy on fermented-cassava pomace. Cassava pomace was fermented aerobically with Aspergillus oryzae using solid state-fermentation (SSF) method for 72 (OF-72) and 144 (OF144) hours, and then was followed by anaerobic incubation for 48 hours. The samples of OF-0, OF-72, and OF-144 was measured for dry matter and crude protein content, soluble protein, amino acids and gross energy. Twelve Lohman strain broiler roosters of 12 weeks old were fasted for 24 hours, then nine of them were fed with non-fermented cassava pomace (OF-0), OF-72 and OF-144 material-test (each was done for three chicks) by using wet forced-feeding technique. After being force-fed, all chicks were fasted and the excreta was collected for $2 \times 24$ hours period. The excreta samples were measured for dry matter, soluble protein and gross energy content. Following the chemical analysis, the true digestibility of dry matter (TDDM), true digestibility of soluble protein (TDSP) and apparent metabolizable energy (AME) were determined. Data was analyzed with one-way ANOVA, followed by Duncan's Multiple Range Test. The result of the research showed that, from OF-0 to OF-72, the percentage of crude protein, soluble protein and the total of 14 amino acids respectively increased into 191,112 and $246 \%$. From OF-72 to OF-144, the nutrients content relatively unchanged, except soluble protein and several amino acids were considerably increased. The value of TDDM and AME were non-significantly changed from OF- 0 to $\mathrm{OF}-72$, and then significantly decreased $(\mathrm{P}<0.05)$ on $\mathrm{OF}-144$. The value of TDSP significantly increased $(\mathrm{P}<0.05)$ from $\mathrm{OF}-0$ to $\mathrm{OF}-72$, and then nonsignificantly decreased on OF-144.
\end{abstract}

(Key words: Cassava pomace, Fermentation, Aspergillus oryzae, Digestibility, Bioavailability energy, Broiler).

\section{Pendahuluan}

Onggok adalah limbah padat berupa ampas dari pengolahan ubikayu menjadi tapioka, yang apabila didiamkan dalam beberapa hari akan menimbulkan bau asam dan busuk yang bersifat mencemari lingkungan (Balitnak, 1994). Produksi ubikayu Indonesia menempati urutan ke 4 terbesar setelah Nigeria, Brazil dan Thailand. Pada tahun 2002, produksi ubi kayu Indonesia mencapai 16,9 juta ton dengan luas areal 1,27 juta ha, yang sebagian besar diserap industri tapioka, sehingga setiap tahun tidak kurang dari 1,2 juta ton onggok dihasilkan (Anonim, 2003). Nutrien utama onggok adalah karbohidrat yaitu 60-70\% (Tisnadjaja, 1996), dengan komponen utama berupa pati
(Judoamidjojo et al., 1992). Nutrien lain yang harus diperhitungkan apabila onggok digunakan sebagai bahan pakan unggas adalah tingginya serat kasar, rendahnya protein, rendahnya kecemaan (Puslitbangnak, 1996), dan adanya senyawa anti-nutrisi (Suliantari dan Rahayu, 1990). Perlakuan fermentasi mikrobiologik dapat meningkatkan kandungan protein, perbaikan kecernaan serta munculnya berbagai asam amino, enzim dan vitamin Muljohardjo (1988), Haris dan Karmas (1989) dan Judoamidjojoet al. (1992).

Onggok merupakan limbah industri yang sangat potensial digunakan dalam solid-state fermentation (SSF) (Djide, 1990; Judoamidjojo et al., 1992; Silalahi et al., 1993; Balitnak, 1994), serta mampu menghasilkan enzim ekstra seluler 
dan biomasa yang mengandung semua asam amino yang dibutuhkan hewan (Wainwright, 1992). Aspergillus oryzae merupakan mikroba amilolitik (Djide, 1990; Terebiznik et al., 1996) sekaligus selulolitik (Rapper and Fennel, 1977). Fermentasi dengan $A$, oryzae mampu meningkatkan protein sejati, menurunkan serat kasar (Hanim et al., 1999) dan menghasilkan beberapa vitamin seperti asam pantotenat, inositol, tiamin, piridoksin, biotin dan vitamin B12 (Rapper and Fennel, 1977). Protein tepung ubikayu meningkat dari 0,12 menjadi $17 \%$ dengan fermentasi menggunakan Candida tropicalis (Balitnak, 1994), sedangkan dengan $A$. niger kandungan protein sejati onggok meningkat fantastis dari 2 menjadi $8 \%$ (Puslitbangnak, 1996), serta terbentuk edible protein dengan Rhizopus oryzae (Tanuwidjaja dan Anah, 1989).

Penelitian ini bertujuan mempelajari: 1) perubahan kandungan protein kasar, protein terlarut, dan asam amino pada onggok yang diberi perlakuan fermentasi substrat padat menggunakan $A$. oryzae; dan 2) ketersediaan energi-termetabolis, kecernaan sejati bahan kering dan kecernaan sejati protein terlarut onggok-fermentasi pada ayam broiler.

\section{Materi dan Metode}

\section{Medium fermentasi}

Onggok kering giling dicampur dengan air dengan perbandingan $1: 1$, dikukus selama 60 menit, kemudian didinginkan sampai mencapai suhu kamar. Selanjutnya onggok dicampur secara merata dengan $1 \%(\mathrm{w} / \mathrm{w})$ urea dan $0,1 \%$ (v/w) medium Czapek's yang dimodifikasi $(5 \mathrm{~g}$ $\mathrm{NaNO}_{3}, 1 \mathrm{~g} \mathrm{~K} \mathrm{HPO}_{4}, 1 \mathrm{~g} \mathrm{KH_{2 }} \mathrm{PO}_{4}, 0,5 \mathrm{~g} \mathrm{KCl}$, $0,01 \mathrm{~g} \mathrm{FeSO} \cdot 7 \mathrm{H}_{2} \mathrm{O}, 0,5 \mathrm{~g} \mathrm{MgSO}_{4} \cdot 7 \mathrm{H}_{2} \mathrm{O}$ dalam $1000 \mathrm{ml}$ akuades) berdasarkan bahan kering onggok.

\section{Inokulum}

Aspergillus oryzae diperoleh dari media agar miring koleksi Laboratorium Bioteknologi, Fakultas Teknologi Pertanian, UGM diinokulasikan ke dalam $100 \mathrm{ml}$ medium yang mengandung $1 \mathrm{~g}$ glukosa, medium Czapek's yang dimodifikasi dan $0,3 \quad \mathrm{~g} \quad \mathrm{NaNO}_{3} . \mathrm{pH}$ disesuaikan menjadi sekitar 4 dengan larutan $\mathrm{HCl}$. Inkubasi dilakukan selama 24 jam dalam erlenmeyer pada suhu kamar. Penggandaan dilakukan dengan cara menginkubasikan $10 \%$ $(\mathrm{v} / \mathrm{v})$ inokulum cair dalam medium cair.

\section{Inkubasi dan panen}

Sepuluh persen (v/w) inokulum cair dicampurkan secara merata dengan substrat onggok, kemudian ditebarkan (ketebalan $2 \mathrm{~cm}$ ) pada rak beralas strimin yang telah dicuci dengan deterjen yang dilanjutkan dengan alkohol $70 \%$. Inkubasi aerobik dibuat dua macam yakni 72 dan 144 jam, yang dilanjutkan inkubasi anaerobik selama 48 jam. Pasca inkubasi anaerobik, onggok-fermentasi dikeringkan di bawah sinar matahari sampai kadar air lebih kecil dari $15 \%$, kemudian digiling dan disimpan dalam kantong plastik tertutup. Onggok-fermentasi diambil sampel dan dimasukkan dalam freezer untuk keperluan analisis laboratorium.

\section{Uji ketersediaan energi dan kecernaan}

Pengukuran pada uji ini menggunakan metode total koleksi. Dua belas ekor ayam broiler jantan umur 12 minggu secara acak dimasukkan dalam kandang batere individual yang di bawahnya telah dilengkapi dengan penampung ekskreta. Percobaan menggunakan rancangan acak lengkap pola searah (RAL) dengan tiga macam perlakuan pakan-uji berupa onggok non-fermentasi (OF-0), onggokfermentasi 72 (OF-72), dan 144 jam (OF-144). Setiap perlakuan digunakan 3 ekor ayam sebagai ulangan.

Mengacu pada Lessire (1990), semua ayam dipuasakan selama 24 jam, mulai pukul 09.00. Pukul 09.00 hari berikutnya, dilakukan pelolohan basah pakan-uji yang sebelumnya telah digiling halus, dicampur dengan air dengan perbandingan 1:2 sampai terbentuk pasta. Kuantitas pelolohan sekitar $80 \mathrm{~g} /$ ekor terhadap sembilan ekor ayam. Tiga ekor ayam sisanya tidak diberi pakan sama sekali, untuk mengetahui protein endogen. Semua ayam dipuasakan lagi sambil dilakukan koleksi ekskreta selama dua kali 24 jam. Ekskreta- 
terkoleksi dikeringkan di bawah sinar matahari selama tiga hari, ditimbang untuk mengetahui kuantitas ekskreta, digiling, dibungkus dalam plastik dan dimasukkan freezer.

Sampel ekskreta-terkoleksi dan pakan-uji diukur besarnya kandungan bahan kering (dry matter, DM), gross energy (GE) menggunakan bom kalorimeter otomatis "Gallenkamp Autobomb", dan protein terlarut menggunakan metode Folin-Lowry. Penghitungan apparent metabolizable energy (AME), true digestibility of dry matter (TDDM) dan true digestibility of soluble protein (TDSP) berturut-turut menggunakan rumus:

$$
A M E=G E_{\text {pakan-uji }}-\left(\frac{D_{\text {ekskreta }}}{D M_{\text {intake }}}\right) \times G_{\text {ekskreta }}
$$

$$
\begin{aligned}
& \% \text { TDDM }=\frac{\left[\mathrm{DM}_{\text {intake }}-\left(\mathrm{DM}_{\text {elskreta }}-\mathrm{DM}_{\text {endogen }}\right)\right]}{\mathrm{DM}_{\text {intake }}} \times 100 \\
& \% \mathrm{TDSP}=\frac{\left[\mathrm{SP}_{\text {intake }}-\left(\mathrm{SP}_{\text {ekskreta }}-\mathrm{SP}_{\text {endogen }}\right)\right]_{\mathrm{N}}}{\mathrm{SP}_{\text {intake }}} \times 100
\end{aligned}
$$

Keterangan: endogen berasal dari ekskretaterkoleksi ayam yang tidak diberi pakan-uji.

\section{Analisis statistik}

Untuk mengetahui perbedaan nilai AME, TDDM dan TDSP antara perlakuan OF-0, OF-72 dan OF-144 dilakukan analisis variansi RAL pola searah, yang dilanjutkan dengan uji Duncan's (Gill, 1981).

\section{Analisis nutrien}

Analisis kandungan air menggunakan teknik pemanasan $105^{\circ} \mathrm{C}$, sedangkan protein kasar menggunakan metode Kjeldahl (AOAC, 1990). Penentuan kandungan protein terlarut menggunakan metode Folin-Lowry dengan larutan standar bovine serum albumin (BSA) yang ditera dengan spektrofotometer pada panjang gelombang $590 \mathrm{~nm}$ (Sudarmadji et al., 1984).
Kandungan asam amino diukur dengan teknik HPLC. Sampel bahan dihidrolisis dengan $\mathrm{HCl} 6 \mathrm{~N}$ pada suhu $110^{\circ} \mathrm{C}$ selama 24 jam dan direaksikan dengan reagen ortho phetaldialdehyde (OPA) selama 5 menit, kemudian diijeksikan pada rangkaian HPLC. Perlakuan yang sama dilakukan pada larutan asam amino standar yang telah diketahui konsentrasinya. Jenis asam amino ditentukan dengan membandingkan waktu retensi dan profil grafik serapan larutan sampel dengan larutan asam amino standar pada HPLC. Konsentrasi masing-masing asam amino sampel diperoleh dengan rumus:

$$
\% \text { asamamino }=\frac{\left\{\left[\frac{(\mathrm{A} \times \mathrm{K} / \mathrm{B}}{\mathrm{C}}\right] \times \mathrm{D} \times \mathrm{E} \times \mathrm{F}\right\}}{\text { berat sampel }(\mu \mathrm{g})}
$$

$\mathrm{A}=$ luas area puncak larutan sample; $\mathrm{B}=$ luas area puncak larutan asam amino standar; $C=$ volume injeksi larutan sampel (1); $D=$ konsentrasi larutan asam amino standar $(\mathrm{mol} / \mathrm{ml}) ; \mathrm{E}=$ tingkat pengenceran sampel $(10$ $\mathrm{ml}) ; \mathrm{F}=$ berat molekul asam amino $(\mathrm{g} / \mathrm{mol}) ; \mathrm{K}=$ volume injeksi larutan asam amino standar (1).

\section{Hasil dan Pembahasan}

\section{Protein dan asam amino}

Kandungan protein kasar, protein terlarut, dan 14 asam amino onggok non-fermentasi (OF$0)$, OF-72, dan OF-144 terlihat pada Tabel 1.

Persentase protein kasar, protein terlarut dan jumlah 14 asam amino meningkat tajam setelah onggok terfermentasi selama 72 jam, kemudian terjadi peningkatan sedikit dengan penambahan waktu inkubasi menjadi 144 jam, kecuali protein terlarut yang masih meningkat tajam.

Peningkatan protein kasar, protein terlarut dan jumlah 14 asam amino berturut-turut sebesar 191, 112, dan $246 \%$ pada onggok yang difermentasi 72 jam. 
Tabel 1. Kandungan protein dan jumlah 14 asam amino pada onggok yang diberi perlakuan fermentasi substrat padat dengan lama inkubasi 72 jam dan 144 jam. (Content of proteins and total of 14 amino acids in cassava pomace treated by solid-substrate fermentation for 0 (OF-0), 72 hours (OF-72), and 144 hours (OF-144) incubation)

\begin{tabular}{lccc}
\hline \multirow{2}{*}{ Peubah (Variable) } & \multicolumn{3}{c}{ Perlakuan (Treatment) } \\
\cline { 2 - 4 } & OF-0 & OF-72 & OF-144 \\
\hline Protein kasar (Crude protein) (\%) & 2,11 & 6,13 & 6,41 \\
Protein terlarut (Soluble protein) (\%) & 1,66 & 3,51 & 6,06 \\
Jumlah 14 asam amino (Total of 14 amino acids) (\%) & 0,68 & 2,35 & 2,43 \\
\hline
\end{tabular}

Peningkatan protein ini selaras dengan Balitnak (1994) yang memfermentasi tepung ubikayu, dan Puslitbangnak (1996) yang menemukan peningkatan kandungan protein sejati pada fermentasi onggok dengan $A$. niger, dan Hanim et al. (1999) yang memfermentasi bungkil inti kelapa sawit dengan $A$. oryzae. Peningkatan protein dalam proses fermentasi dapat diakibatkan oleh terbentuknya protein sel tunggal (Jay, 1986; Mendoza et al., 1994) dan asam amino (Hrubant, 1985; Ghanem et al., 1991) selama mikroba mengalami pertumbuhan.

Respon fermentasi terhadap protein kasar dan jumlah 14 asam amino menunjukkan bahwa 72 jam pertama masa inkubasi, $A$. oryzae mengalami pertumbuhan cepat (fase logaritmik), setelah itu laju pertumbuhan menurun mendekati konstan (fase stasioner). Rachman (1989) dan Judoamidjojo et al. (1992) menyatakan bahwa pada saat fase pertumbuhan logaritmik, proses fermentasi akan menghasilkan metabolit primer seperti asam amino, glukosa dan senyawa sederhana lain untuk memenuhi kebutuhan nutrien mikroba. Selanjutnya dilaporkan bahwa setelah fase logarirmik akan dilanjutkan fase stasioner, dimana pada fase ini mulai dihasilkan metabolit sekunder seperti antibiotik (Wainwright, 1992) yang dapat menekan laju pertumbuhan mikroba.

Profil 14 asam amino akibat proses fermentasi dengan $A$. oryzae dapat dilihat pada Gambar 1.

Proses fermentasi selama 72 jam mengakibatkan 14 macam asam amino mengalami peningkatan yang tinggi kecuali metionin. Hal ini sesuai dengan Jay (1986) dan Ghanem et al. (1991) yang menyatakan bahwa produksi asam amino pada proses fermentasi cukup tinggi kecuali metionin. Peningkatan asam amino akibat proses fermentasi dilaporkan juga Cronk et al. (1977) yang disitasi Merican dan Yeoh (1989) dan Hrubant (1985).

Penambahan masa inkubasi dari 77 menjadi 144 jam mengakibatkan sebagian asam amino mengalami peningkatan yang cukup tinggi, sebagian meningkat sedikit, bahkan ada yang menurun. Peningkatan yang cukup tinggi dialami oleh fenilalanin dan lisin. Kandungan glutamat dan valin meningkat sedikit. Kandungan metionin, leusin dan arginin tidak mengalami perubahan, sedangkan treonin, alanin dan isoleusin sudah mengalami penurunan.

\section{Kecernaan dan ketersediaan energi}

Kecernaan bahan kering, protein dan ketersediaan energi onggok dan onggokfermentasi yang dicobakan pada ayam broiler jantan dapat dilihat pada Tabel 2.

Fermentasi menggunakan $A$. oryzae pada onggok secara nyata $(\mathrm{P}<0,05)$

mengakibatkan perubahan terhadap TDDM, TDSP, dan AME.

Fermentasi selama 72 jam (KTRL menjadi OF-72) mengakibatkan perubahan yang tidak nyata terhadap TDDM dan AME, sedangkan TDSP mengalami peningkatan nyata $(P<0,05)$. Penambahan lama inkubasi menjadi 


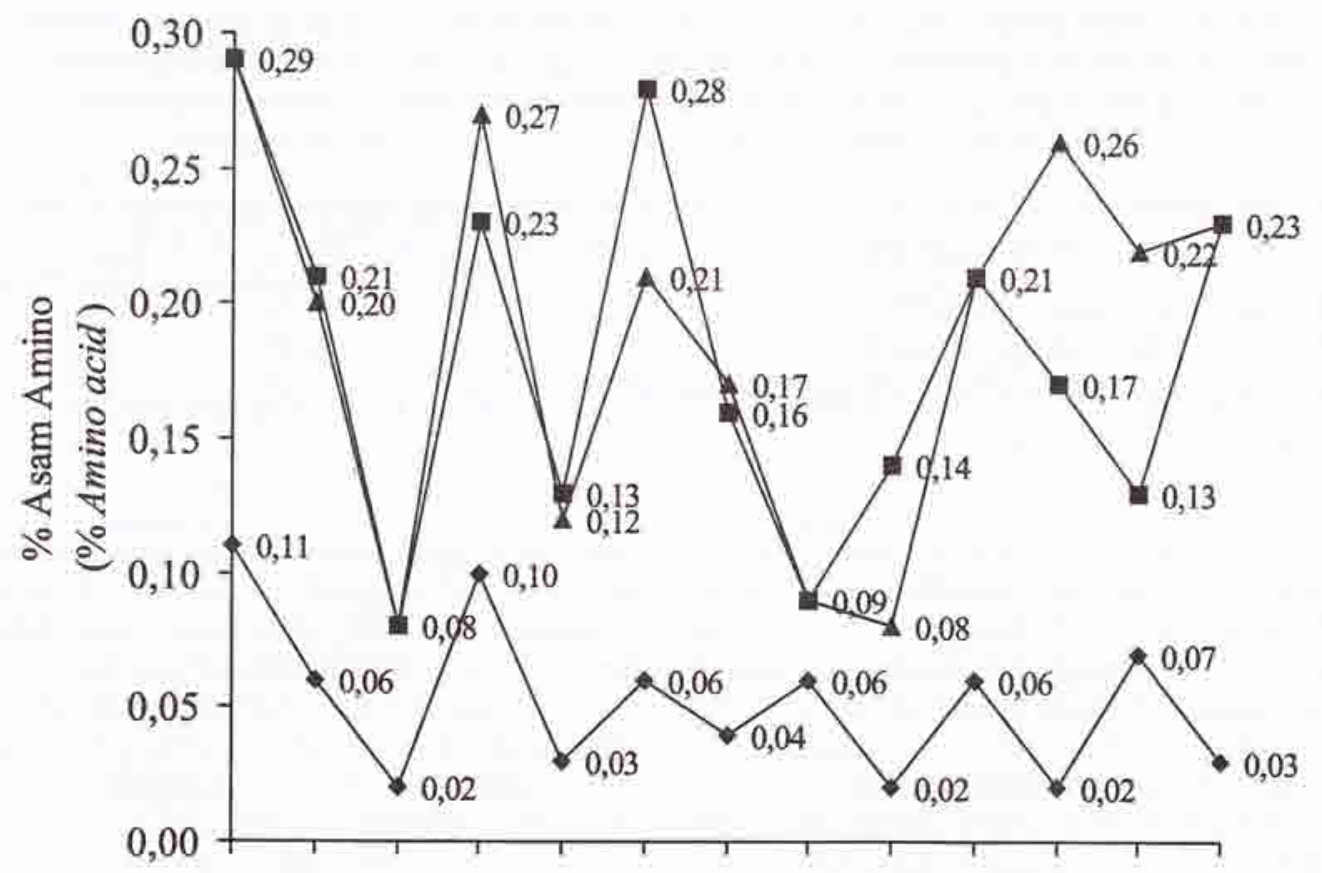

Asp Thr Ser Glu Gly Ala Val Met lle Leu Phe Lys Arg

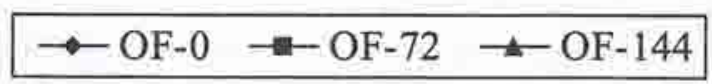

Gambar 1. Profil 14 Asam amino pada onggok yang diberi perlakuan fermentasi substrat padat dengan lama inkubasi 0 (OF-0), 72 (OF-72), dan 144 jam (OF-144). (Profile of 14 amino acids in cassava pomace treated by solid-substrate fermentation for 0 (OF-0),

72 (OF-72), and 144 hours (OF-144) incubation).

Tabel 2. TDDM, TDSP, dan AME onggok non-fermentasi (KTRL), OF-72, dan OF-144 pada ayam broiler jantan umur 12 minggu (TDDM, TDSP, and AME in nor-fermented cassava pomace (KTRL), $O F-72$, and (OF-144) on 12 weeks old of broiler roasters)

\begin{tabular}{lccc}
\hline Variabel (Variables) & \multicolumn{3}{c}{ Pakan-uji (material-test) } \\
\cline { 2 - 4 } & OF-0 & OF-72 & OF-144 \\
\hline TDDM, \% & $73,70^{\mathrm{a}}$ & $72,31^{\mathrm{a}}$ & $60,55^{\mathrm{b}}$ \\
TDSP, $\%$ & $41,67^{\mathrm{b}}$ & $72,15^{\mathrm{a}}$ & $58,53^{\text {ab }}$ \\
AME, kcal/kg & $2895^{\mathrm{a}}$ & $2952^{\mathrm{a}}$ & $2393^{\mathrm{b}}$ \\
\hline
\end{tabular}

${ }^{\mathrm{ab}}$ Superskrip pada baris yang sama menunjukkan perbedaan nyata $(\mathrm{P}<0,05)$ (means within the same row with different superscript are significant differences $(P<0.05))$. 
144 jam, TDDM dan AME mengalami penurunan nyata $(\mathrm{P}<0,05)$, sedangkan TDSP menurun secara tidak nyata.

Secara statistik menunjukkan bahwa proses fermentasi selama 72 jam tidak mengubah kecernaan in vivo bahan kering (TDDM) dan ketersediaan energi (AME) bagi ayam. Penurunan nyata TDDM dan AME terjadi setelah inkubasi ditambah menjadi $144 \mathrm{jam}$. Hal ini mungkin disebabkan jamur telah banyak yang membentuk spora. Seperti diketahui, sel spora mempunyai rigiditas yang tinggi (Hutagalung, 1977 yang disitasi Sinurat et al., 1995) sehingga menurunkan kecernaan maupun ketersediaan energi-termetabolis bagi ayam.

Peningkatan nyata kecernaan protein terlarut (TDSP) akibat proses fermentasi 72 jam (KTRL menjadi OF-72) selaras dengan Surisdiarto (1999) yang melaporkan peningkatan kecernaan protein kasar pakan ayam petelur akibat substitusi $100 \%$ bekatul dengan fermentasi campuran onggok dan kotoran ayam. Zyla et al. (2000) juga melaporkan adanya penurunan viskositas digesta dan ketersediaan fosfor bukan fitat pada pakan berbasis gandum yang disuplementasi miselium jamur $A$. niger, Penurunan viskositas digesta merupakan indikasi menurunnya polisakarida bukan pati, suatu karbohidrat yang tidak dapat dicerna ayam. Selanjutnya disebutkan bahwa miselium jamur kaya akan enzim-enzim intraseluler dan membrane bound yang dapat meningkatkan ketersediaan nutrien pakan di saluran pencernaan. Pada fermentasi 72 jam, jamur dalam fase pertumbuhan cepat dengan sel berbentuk miselium.

\section{Kesimpulan}

Fermentasi onggok menggunakan $A$. oryzae selama 72 jam mengakibatkan kandungan protein kasar, protein terlarut dan jumlah 14 asam amino mengalami peningkatan berturut-turut sebesar 191,112 dan $246 \%$. Penambahan inkubasi menjadi 144 jam tidak mengubah kandungan protein kasar, kecuali protein terlarut dan beberapa asam amino yang masih menunjukkan peningkatan yang tinggi.
TDDM dan AME tidak berubah dengan fermentasi 72 jam, sedangkan TDSP meningkat. TDDM dan AME menurun setelah inkubasi ditambah menjadi 144 jam, sedangkan TDSP berubah.

\section{Daftar Pustaka}

Anonim. 2003. Produksi Tanaman Padi dan Palawija di Indonesia. Biro Pusat Statistik. Jakarta.

AOAC. 1990. Official Methods of Analysis. $15^{\text {th }}$ ed. Association of Official Analytical Chemists. Washington, D.C.

Balitnak. 1994. Pemanfaatan Limbah Pertanian dan Limbah Pengolahan Tapioka/Sagu sebagai Pakan Ternak. Warta Penelitian dan Pengembangan Pertanian, 4: 7 .

Djide, N. 1990. Isolasi dan karakterisasi kapang pemecah pati dari limbah pabrik tapioka: kondisi optimum produksi enzim pemecah pati. Bulletin Pascasarjana Seri Sains, 4: 48-55.

Ghanem, K. M., A. H. El-Refai and M. A. ElGazaerly, 1991. Protein-enriched feedstuff from beet pulp. World Journal of Microbiology and Biotechnology, 7: 365371.

Gill, J. L. 1981. Design and Analysis of Experiments in The Animal and Medical Sciences. Volume 1. Iowa State University Press. Ames, Iowa.

Hanim, C., Z. Bachrudin, dan Ali-Agus. 1999. Evaluasi nilai nutrisi bungkil inti kelapa sawit yang difermentasi dengan jamur. Buletin Peternakan, 23(2): 81-87.

Haris, R. S. dan E. Karmas. 1989. Evaluasi Gizi pada Pengolahan Pangan. Terbitan ke-2. Penerbit ITB. Bandung.

Hrubant, G. R. 1985. Fermentative upgrading of wastes for animal feeding. in wood, b. . . b. microbiology of fermented foods. Elsevier Applied Science Publishers, 2:113-131

Jay, J. M. 1986. Food Microbiology. $8^{\text {th }}$ ed. Van Nostrand Rienhold. New York.

Judoamidjojo, M., A. A. Darwis, dan E. G. Said. 1992. Teknologi Fermentasi. Rajawali Pers. Jakarta. 
Lessire. 1990. Effect of the feeding technique: ad libitum, dry or wet force feeding on the metabolizable energy value of raw materials for poultry. Brit. Poult. Sci., 31: 785-743.

Mendoza, N. S., M. Arai, T. Kawaguchi, F. S. Cubol, E. G. Panerio, T. Yoshida, and L. M. Jonson. 1994. Isolation of mannanutilizing bacteria and the culture conditions for mannanase production. World Journal of Microbiology and Biotechnology, 10(1):51-54.Abstr.

Merican, Z. and Q. L. Yeoh. 1989. Tapai Processing in Malaysia: A Technology in Transition. In K.H. Steinkraus. Industrialization of Indigenous Fermented Foods. Marcel Dekker Inc. New York.

Muljohardjo, M. 1988. Teknologi Pengawetan Pangan. $3^{\text {th }}$ ed. Terjemahan. UI Press. Jakarta.

Puslitbangnak. 1996. Potensi ampas sagu fermentasi dan manfaatnya untuk unggas. Warta Penelitian dan Pengembangan Pertanian, 2(18): 9-12.

Rachman, A. 1989. Pengantar Teknologi Fermentasi. PAU-IPB. Bogor.

Rapper, K.B. and D.I. Fennel. 1977. The Genus Aspergillus. Robert, E Krieger Publ. Co, Huntington, New York.

Silalahi, M., D. Aritonang, J. D. Darma, Tresnawati, dan T. Haryati. 1993. Pemanfaatan ampas singkong terfermentasi dalam ransum babi. Bulletin Peternakan, edisi khusus: 185-193.

Sinurat, A. P., P. Setiadi, A. Lasmini, A. R. Setioko, T. Purwadaria, I. P. Kompiang dan J. Darma. 1995. Penggunaan cassapro (singkong terfermentasi) untuk itik petelur. Ilmu dan Peternakan, 8(2): 28-31.
Sudarmadji, S., B. Haryono, dan Suhardi. 1984. Prosedur Analisa untuk Bahan Makanan dan Pertanian. Penerbit Liberty. Yogyakarta.

Suliantari dan W. P. Rahayu. 1990. Teknologi Fermentasi Biji-bijian dan Umbi-umbian. PAU-IPB. Bogor.

Surisdiarto, H. 1999. Penggunaan fermentasi campuran onggok dan kotoran ayam sebagai pengganti bekatul dalam pakan ayam petelur. Buletin Peternakan, 23(1): $7-14$.

Tanuwidjaja and Anah. 1989. Protein enrichment of cassava solid waste by SSF. In Howghee, A., Hen, N.B. and L.K. Kong (eds). Trends in Food Biotechnology. Proceedings of The $7^{\text {th }}$ Word Congress of Food Science and Technology. 25-28.

Terebiznik, M. R., A. M. R. Pilosof, and S. Moreno. 1996. Effective purification procedure of Aspergillus oryzae alfaamylase from solid state fermentation cultures including concanavalin asepharose. J. Biochemistry, 19:341-354.

Tisnadjaja, J. 1996. Pemanfaatan bahan berpati sebagai bahan baku dalam industri asam sitrat. Warta Biotek, 1(10): 3-5.

Wainwright, M. 1992. An Introduction to Fungal Biotechnology. John Wiley and Sons, Ltd. Baffins Lane, Chichester.

Zyla, K., A. Wikiera, J. Koreleski, S. Swiatkiewicz, J. Piironen, and D.R. Ledoux. 2000. Comparison of the efficacies of a novel Aspergilllus niger mycelium with separate and combined effectiveness of phytase, acid phosphatase, and pectinase in dephosphorylation of wheat-based feeds fed to growing broilers. Poultry Sci. 79:1434-1443. 